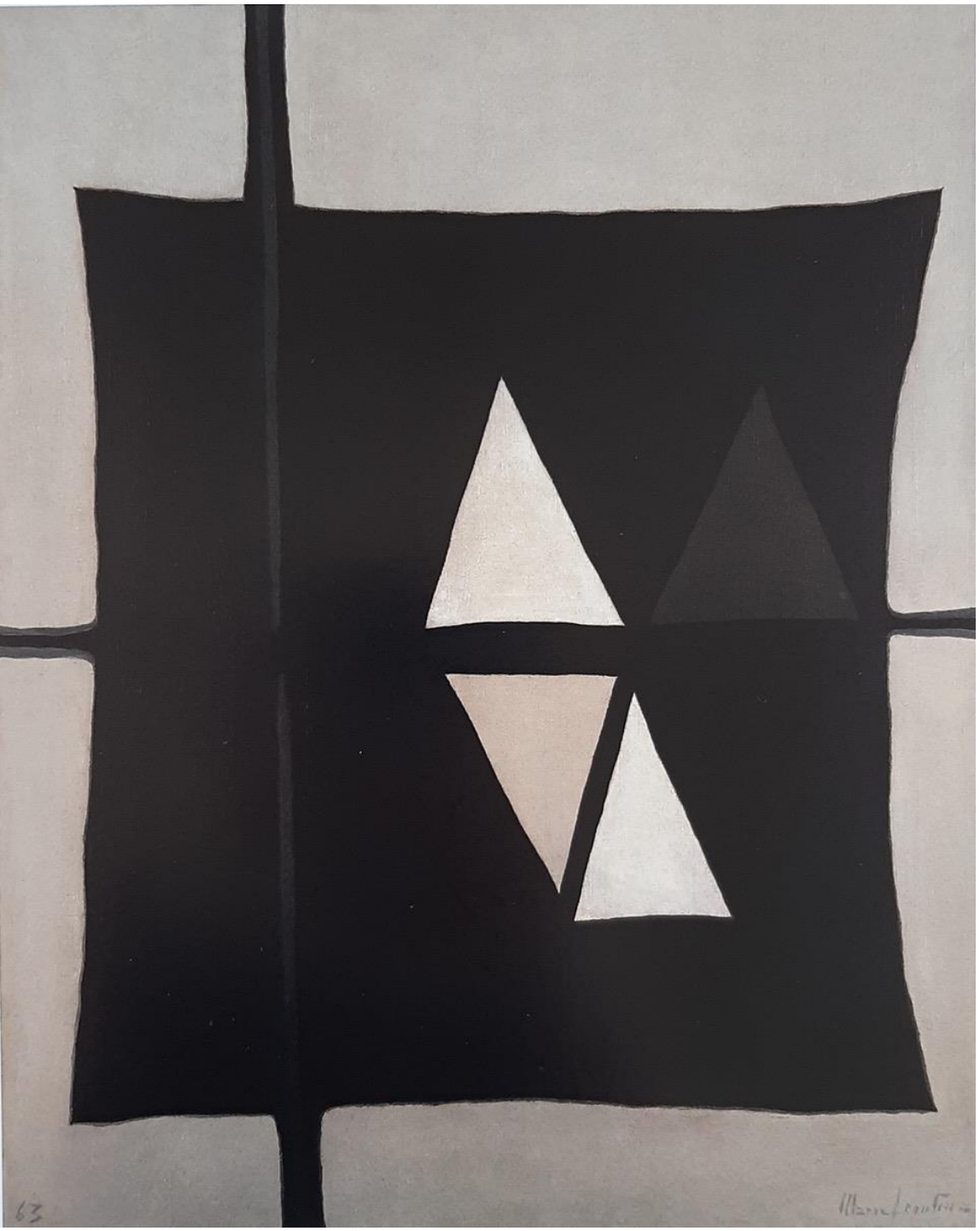

"Desde menina eu me apaixonava pelos objetos": a pintura de Maria Leontina e a geometria sensível

"When I was a girl, I fell in love with objects": pictorial work by Maria Leontina and sensitive geometry

\title{
Priscila Sacchettin
}

Como citar:

SACCHETTIN, P. "Desde menina eu me apaixonava pelos objetos": A pintura de Maria Leontina e a geometria sensível. MODOS: Revista de História da Arte, Campinas, SP, v. 5, n. 1, p. 250-268, 2021. DOI: 10.20396/modos.v5i1.8663995. Disponível em: https://periodicos.sbu.unicamp.br/ojs/index.php/mod/article/view/866 3995.

Imagem: Maria Leontina. Estandarte V, 1963, o.s.t., $100,6 \times 81,3 \mathrm{~cm}$. Coleção MAC-USP (Herkenhoff, 2010: 197). 


\title{
"Desde menina eu me apaixonava pelos objetos": a pintura de Maria Leontina e a geometria sensível

\author{
"When I was a girl, I fell in love with objects": pictorial work by Maria \\ Leontina and sensitive geometry
}

Priscila Sacchettin*

\begin{abstract}
Resumo
Partindo do termo "geometria sensível", analiso a obra pictórica de Maria Leontina Franco da Costa, elegendo como recorte temporal o período entre o final da década de 1940 e o início da década de 1960. Pretendo examinar as implicações formais e poéticas da permanência da alusão figurativa no trabalho da artista, que no entanto se desdobra no campo da abstração. Para isso, faço um breve percurso comentado por telas do período mencionado, e considero também depoimentos da artista a respeito de sua prática. Demonstro assim como o posicionamento estético de Leontina aponta para uma problematização do abstracionismo, na medida em que opera com a conciliação - e não a ruptura - entre abstrato e figurativo.
\end{abstract}

\section{Palavras-chave}

Abstração. Figuração. Geometria sensível. Pintura moderna. Maria Leontina.

\begin{abstract}
Starting from the term "sensitive geometry", I analyze the pictorial work by Maria Leontina Franco da Costa, choosing the period between the end of the 1940s and the beginning of the 1960s as a time frame. I intend to examine the formal and poetic implications of the permanence of figurative allusions in the artist's work, which nevertheless unfolds in the field of abstraction. For this, I survey paintings from the period mentioned, and I also consider the artist's testimonies regarding her artistic practice. I thus demonstrate how Leontina's aesthetic position points to a problematization of abstraction, insofar as it works with the conciliation - and not the rupture - between abstract and figurative.
\end{abstract}

\section{Keywords}

Abstraction. Figuration. Sensitive geometry. Modern painting. Maria Leontina. 
A exposição América Latina: Geometria sensível foi realizada no Museu de Arte Moderna do Rio de Janeiro entre junho e julho de 1978, com curadoria do crítico Roberto Pontual, responsável também por coordenar o catálogo homônimo. Como justificativa, Pontual menciona o crescente interesse pela arte latino-americana naquele período, tanto no Brasil quanto internacionalmente ${ }^{1}$. Desse modo, o curador considerava necessário "encarar e assumir cautelosamente os esforços de busca (...) de um caráter específico da América Latina" (Pontual, 1978a: 8).

A mostra consistia em dois núcleos distintos e interligados, propondo um arco temporal que revelasse continuidades e diálogos entre o começo do século XX e o momento histórico do evento. O primeiro núcleo era formado por obras do uruguaio Joaquín Torres García - que o curador classifica como "construtivo-simbólicas" e considera "uma das matrizes fundamentais do interesse pelo rigor e a disciplina na arte deste continente" (Pontual, 1978a: 8). O segundo núcleo era composto por 26 artistas latino-americanos então vivos, "todos concentrados na preocupação por um trabalho precisamente construído". No total, foram cerca de 200 obras expostas, entre pinturas, desenhos, esculturas e objetos ${ }^{2}$.

Anteriormente à exposição, o termo "geometria sensivel" já era empregado pelos críticos argentinos Damián Bayón e Aldo Pellegrini, que voltaram a utilizá-lo em suas colaborações para o catálogo da mostra. $O$ termo buscava conceituar de modo sintético especificidades da expressão latino-americana, definir e articular características particulares da arte abstrata praticada na região. Era uma tentativa bastante ousada, que aproximava artistas tão diferentes entre si quanto Alfredo Volpi, Amilcar de Castro, Antonio Dias, Arcangelo lanelli, Eduardo Sued, Luiz Sacilotto, Mira Schendel e Rubem Valentim, para ficar apenas nos exemplos brasileiros.

Obras de Maria Leontina não foram expostas no MAM RJ mas, no ensaio que escreveu para o catálogo, o curador comenta o trabalho dela e reproduz uma de suas telas, Estandarte V [Fig. 12], da coleção do Museu de Arte Contemporânea da Universidade de São Paulo ${ }^{3}$ (Pontual, 1978b: 59). A partir de então, a expressão "geometria sensível" é associada à pintura de Leontina em textos críticos de autores que acompanharam seu percurso, como Walmir Ayala, Lélia Coelho Frota, Paulo Herkenhoff e o próprio Roberto Pontual. Parece haver, portanto, certo consenso na atribuição do termo a seu trabalho. Mas 0 que significa dizer que a pintora era adepta de uma "geometria sensível", de resto um termo bastante amplo? Proponho a seguir algumas reflexões sobre a obra de Maria Leontina, na tentativa de particularizar aquele conceito, de modo a perceber quais são os desdobramentos em seu trabalho, tanto na formalização quanto nas possíveis interpretações.

1.

No catálogo América Latina: Geometria sensivel, Roberto Pontual escreve que "o lirismo em Maria Leontina diz respeito à permanência do mundo objetivo na obra" (Pontual, 1978b: 64). A afirmação merece um exame, que farei tendo como guia a questão da permanência do objeto, mesmo se tratando de uma pintura que se desdobra no campo da abstração. Poderíamos, assim, compreender como essa permanência enriquece a ideia de uma "geometria sensível".

Quando vincula o lírico à presença do mundo exterior na pintura de Leontina, Pontual coloca a questão de modo a considerar não apenas como essa pintura é feita, mas também o que podemos (ou não) ver nela. É preciso, então, demonstrar o que é a alusão figurativa que aparece de modo constante, indicar onde estão os vestígios de realidade externa que habitam as telas, mesmo as que seriam, digamos, totalmente abstratas e quais as implicações para a interpretação da obra. Para isso, faço a seguir uma 
breve apresentação em ordem cronológica, grosso modo, atentando para particularidades do processo criativo ao qual Leontina se dedicou e para o modo como elaborou a equação figuração-abstração ao longo do tempo.

Natureza-morta (1949) [Fig. 1] pertence ao início da carreira da pintora. É perceptível a dicção expressionista, bastante presente tanto na obra desta artista ${ }^{4}$ quanto no cenário mais geral da pintura brasileira de então. As cores se interpenetram e por vezes se chocam, a atmosfera da cena é nervosa, devido às pinceladas irritadiças e à estridência de algumas cores. Em outra Natureza-morta (1951) [Fig. 2] do mesmo período, o ponto de vista mais próximo dos objetos amplia as áreas de cor. O fundo é formado por planos retangulares, preferencialmente horizontais abaixo do tampo e verticais acima dele, um recurso reiterado em inúmeras outras naturezas-mortas, como expediente de diferenciação do espaço. Nas duas telas, a pintora busca a estruturação pela cor, mas o tratamento cromático em ambas é bem diferente. Nota-se o contraste em comparação com a obra de 1949: repouso e equilíbrio nesta, instabilidade e inquietação naquela. A artista experimenta com a representação de estados emocionais diversos por meio de um mesmo gênero pictórico, joga com os elementos do quadro para chegar a resultados diferentes. Cores vibrantes predominam na tela de 1951, mas a solidez da composição ameniza a vibração dos vermelhos, também relativizados pela localização ao fundo, na lateral, afastados do primeiro plano.

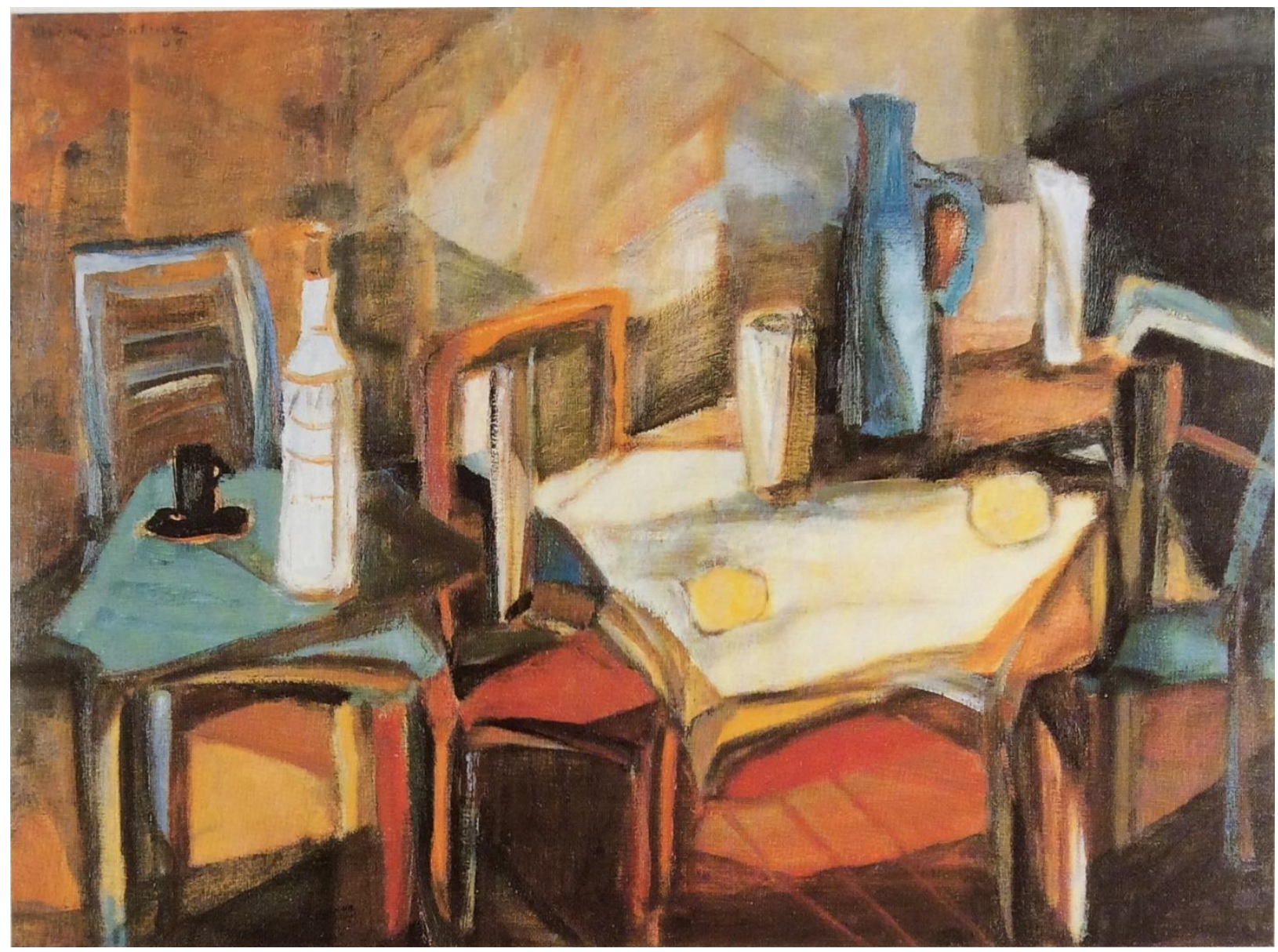

Fig. 1. Maria Leontina. Natureza-morta, 1949, óleo s/ tela, 61 x 85 cm. Col. Paulo Geyerhahn. Fonte: Morais, 1999: 36. 


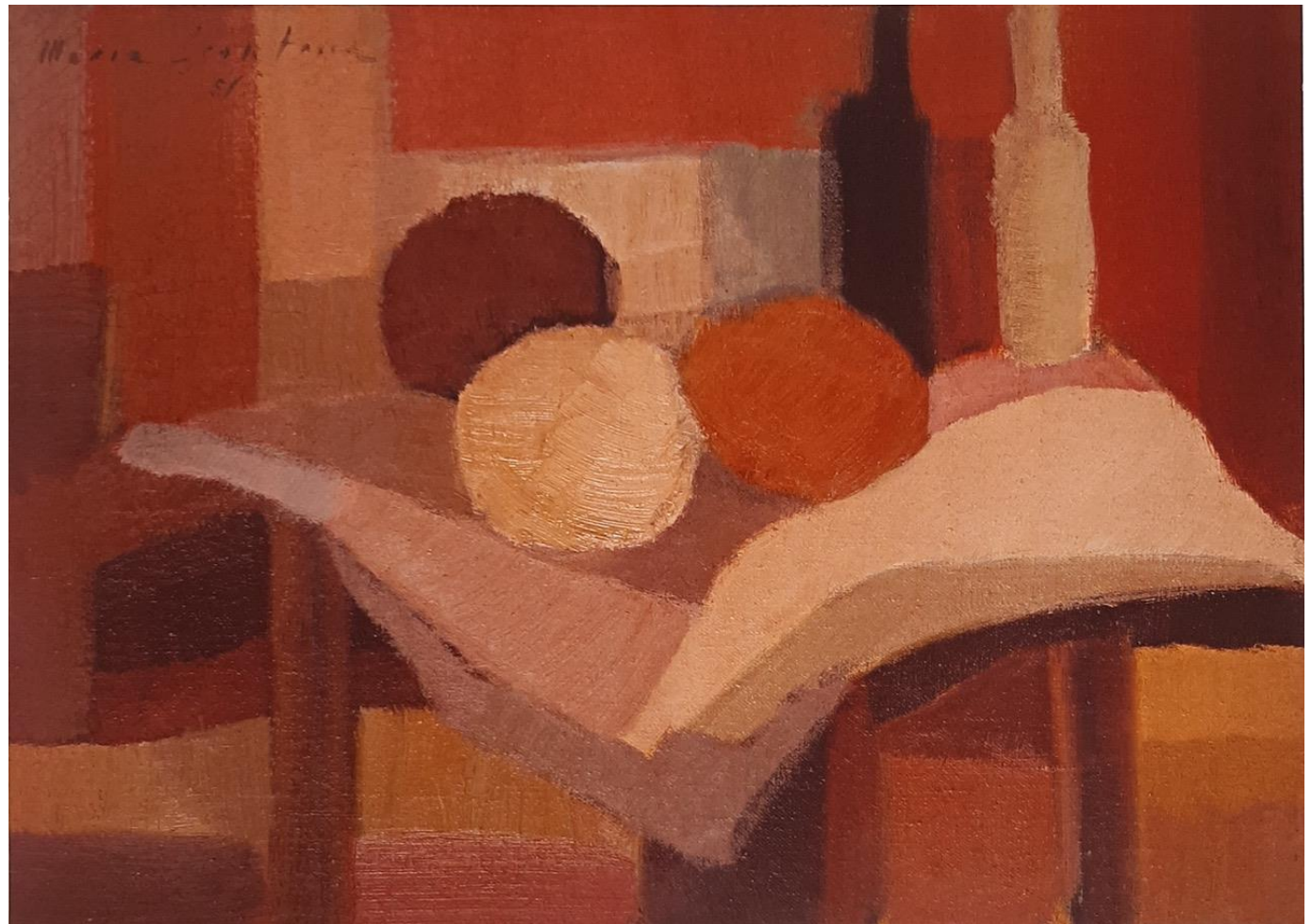

Fig. 2. Maria Leontina. Natureza-morta,1951, óleo s/tela, 24x35 cm. Col. Hecilda e Sergio Fadel. Fonte:Herkenhoff, 2010: 25.

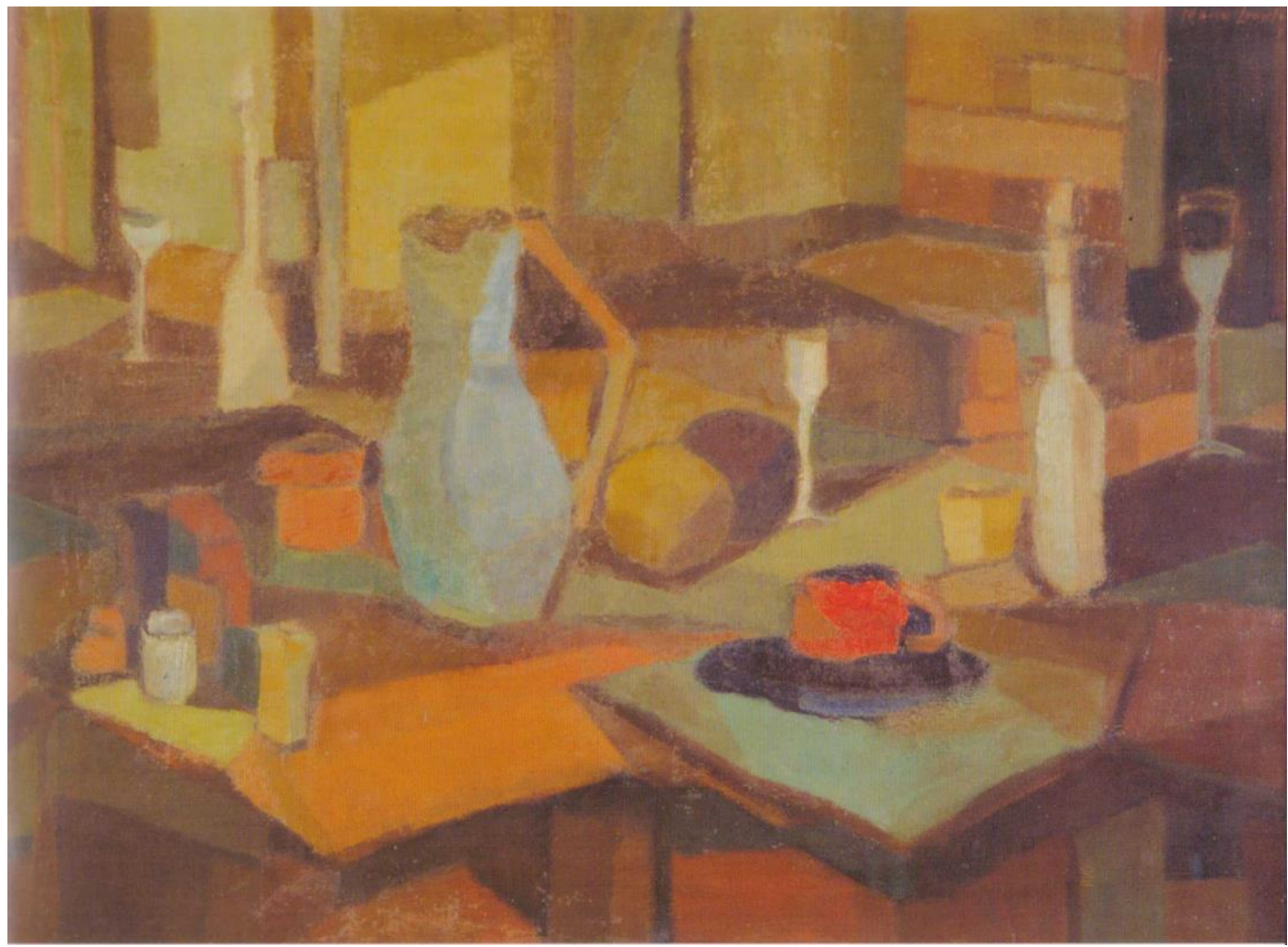

Fig. 3. Maria Leontina. Natureza-morta (Prêmio Aquisição na I Bienal de SP), 1951, óleo s/ tela, 64,4 x $91,5 \mathrm{~cm}$. Col. MAC USP. Fonte: Venancio Filho, 2008: 99. 
A inserção das intensidades cromáticas se transforma em outras obras do período, por exemplo na tela vencedora do prêmio aquisição na I Bienal Internacional de São Paulo, Natureza-morta (1951) [Fig. 3], hoje parte da coleção do MAC USP. Próximo ao primeiro plano, Leontina ousa aplicar um vermelho vivo num detalhe central, atraindo o olhar - a pincelada vigorosa estrutura a xícara que é o polo magnético da composição e por onde começamos a percorrê-la. A pintora parece interessada na investigação do espaço construído por sobreposição de planos, o trabalho tonal apenas sugere o volume dos objetos. Há aqui vestígios da fatura expressionista de telas anteriores, porém, em comparação com elas, percebemos que o espaço se fragmenta e torna-se mais plano.

A Natureza-morta da coleção Andrea e José Olympio (1956) [Fig. 4] é esclarecedora quanto ao processo de abstração da arte de Leontina. Poucos elementos sugerem a figuração: a cafeteira branca, a garrafa verde, quase pura vertical, no limite do reconhecivel, e à sua esquerda a pequena jarra cor de creme. Desaparece a preocupação de modelar, ainda que sutilmente, o volume dos objetos. Os planos de cor, multiplicados, ajustam-se ao ângulo reto.

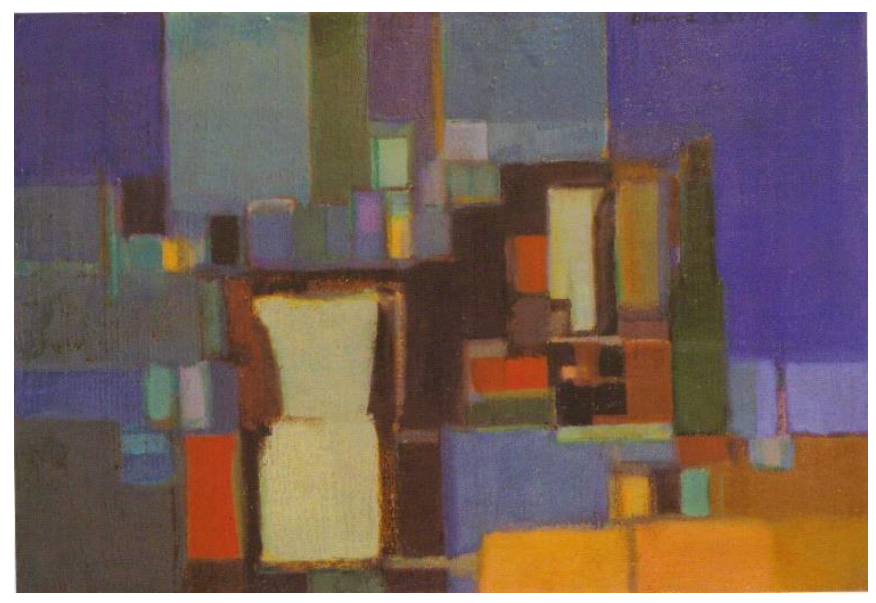

Fig. 4. Maria Leontina. Natureza-morta, 1956, óleo s/ tela, $37,5 \times 55 \mathrm{~cm}$. Col. Andrea e José Olympio Pereira. Fonte: Venancio Filho, 2008: 102.
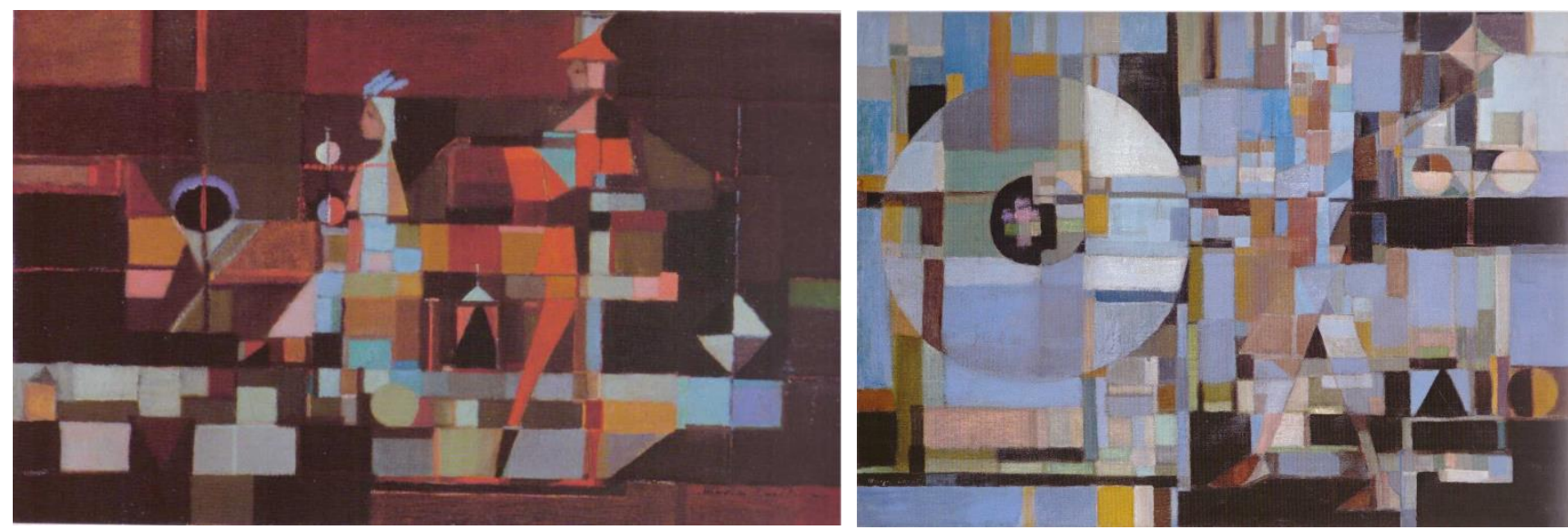

Fig. 5. Maria Leontina. Os Jogos e os Enigmas VI, 1954 ,óleo s/ tela, 33 x $51 \mathrm{~cm}$. Col. Particular. Fonte: Venancio Filho, 2008: 108.

Fig. 6. Maria Leontina. Os jogos e os enigmas, 1954, óleo s/ tela, 59,5 x $81 \mathrm{~cm}$. Col. Particular. Fonte: Herkenhoff, 2010: 130. 
Em outras telas do mesmo período, as figuras assumem uma camuflagem geométrica. É o caso, por exemplo, de Os jogos e os enigmas VI [Fig. 5] e, com mais intensidade, Os jogos e os enigmas [Fig. 6], ambas de 1954. Nestas obras, cuja referência imediata é Maria Helena Vieira da Silva (em telas como O jogo de xadrez (La partie d'échecs), de 1943, na coleção do Centro Pompidou, por exemplo), Leontina experimenta maneiras de geometrizar a figura de modo a levá-la ao limite da correspondência com 0 objeto. É interessante notar como a artista tensiona os limites da figura em meio à abstração que se instala, busca um jeito de pintar que não se paute por um binarismo figuração versus abstração. Assim como em Natureza-morta de 1956 [Fig. 4], a artista testa o que acontece com uma figura absorvida pelas formas geométricas, trabalha de modo a dar ambiguidade à figura, que poderia ser vista tanto enquanto representação, reconhecidos seus contornos, ou converter-se em arranjo de formas puras, segundo o contexto visual em que está.

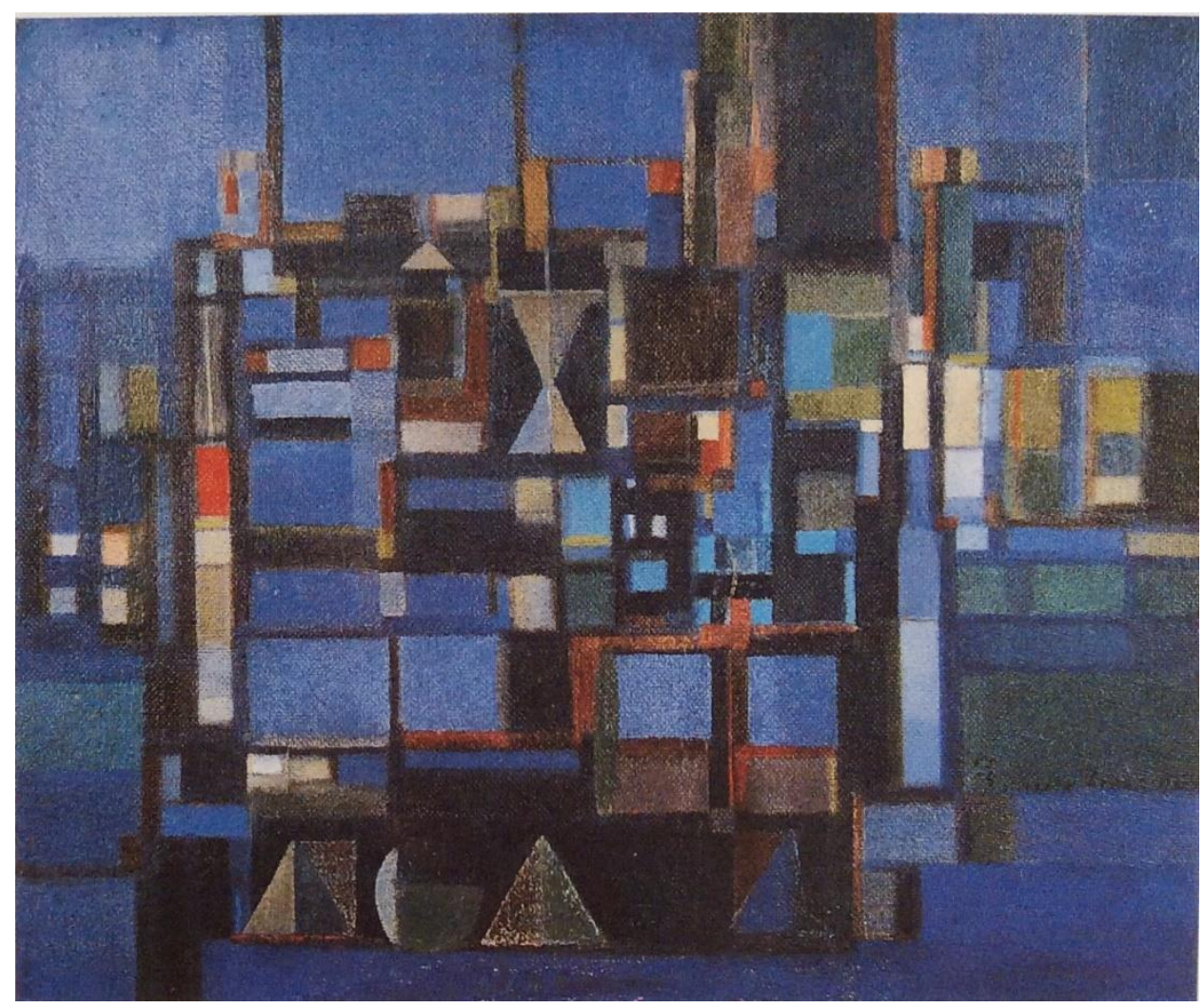

Fig. 7 Maria Leontina. Os jogos IV, 1954. óleo s/ tela, 50 x 61 cm. Col. Gilberto Chateaubriand, RJ. Fonte: Morais, 1999: 50.

Veja-se o caso de Os jogos IV [Fig. 7], contemporânea da série Os Jogos e os Enigmas e aprofundamento do mesmo processo. Parece, a princípio, pura abstração, e podemos de fato olhar dessa maneira. Porém, se observamos os planos de cor que se espalham pela superfície tendo em mente as naturezas-mortas anteriores, acabam por emergir formas familiares, o vocabulário objetual dos anos 1940 e início da década de 1950: garrafas delgadas, taça, bule. Há ainda um vestígio do tratamento dado ao fundo anteriormente: na base da tela predominam as horizontais, na parte superior as verticais - o recurso usado desde o fim da década de 1940 para criar diferenciações no espaço. Não existe uma linha de base que sustente a composição, tampouco uma separação clara entre figura e fundo, porém é nítida a diferenciação entre uma área central densa e fragmentada e as bordas mais espaçadas. Em Os Jogos e os Enigmas V (1955) [Fig. 8], prêmio aquisição da III Bienal de São Paulo, 
a evocação das naturezas-mortas é substituída pela insinuação de uma paisagem urbana: fachadas, portas, janelas, poste.

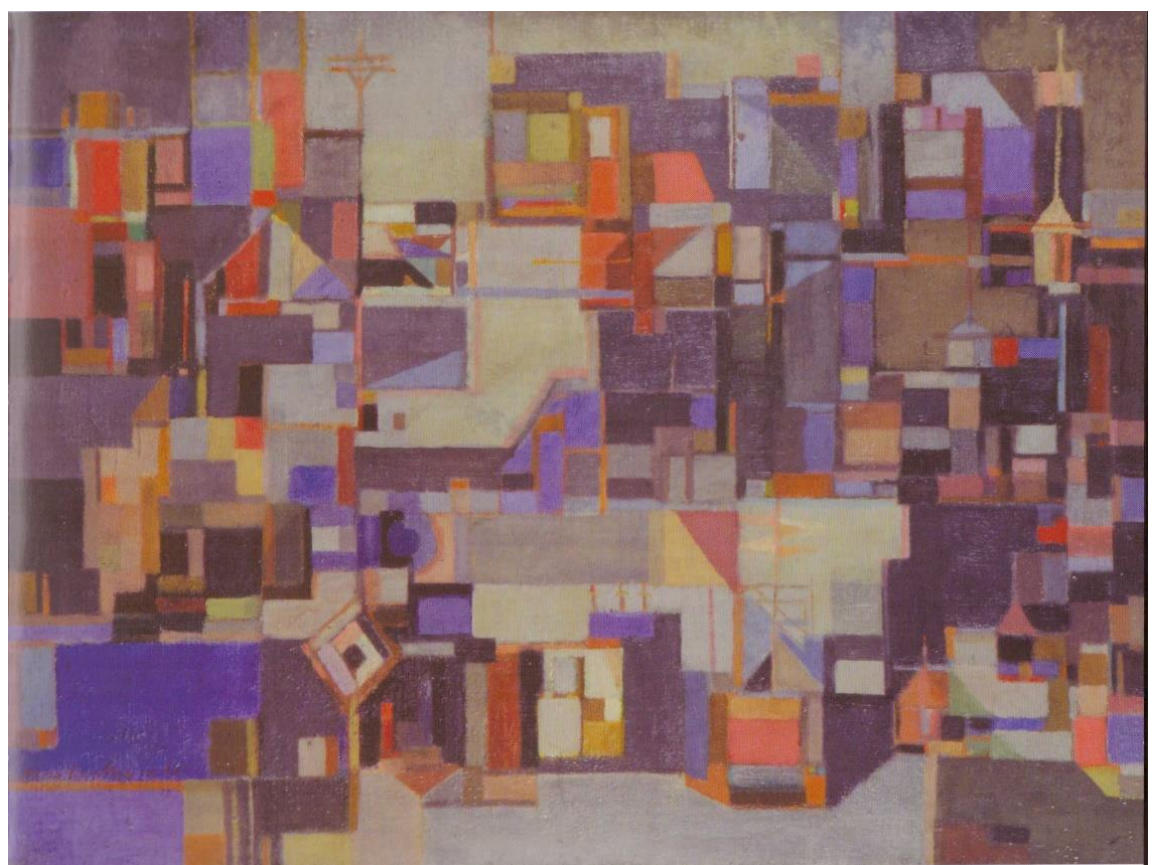

Fig. 8. Maria Leontina. Os Jogos e os Enigmas V (Prêmio Aquisição III BSP), 1955, óleo s/ tela, 75 x 100 cm. MAM RJ. Fonte: Venancio Filho, 2008: 51.

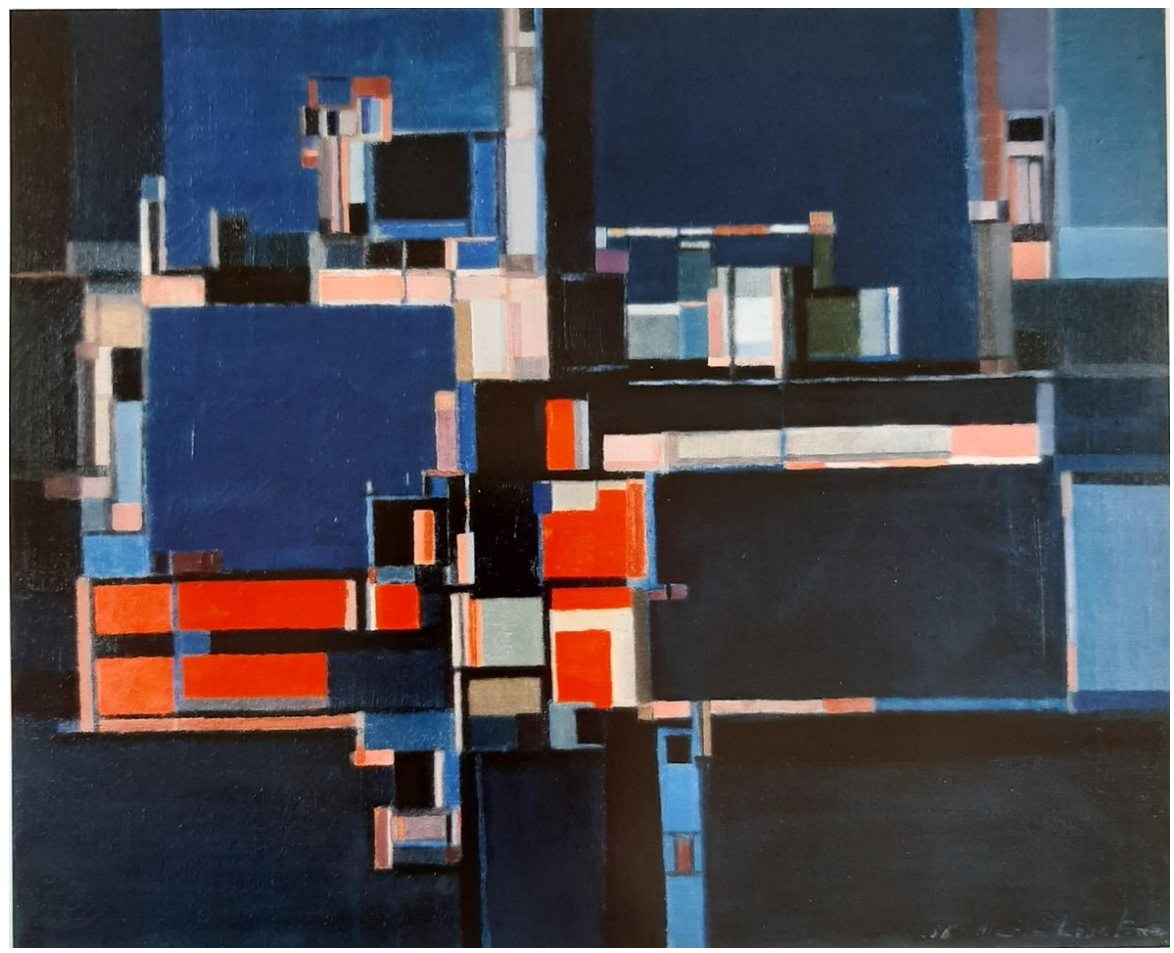

Fig. 9. Maria Leontina. Composição, 1956, óleo s/ tela, 49,5 x 61 cm. Col. Patricia Phelps de Cisneros. Fonte: Herkenhoff, 2010: 13. 
Por vezes, em obras como Composição (1956) [Fig.9], da coleção Patricia Phelps de Cisneros, a fragmentação dá lugar a um certo desejo de ordem, os planos de cor antes estilhaçados voltam a se coagular no centro da tela, sem que, no entanto, a distribuição obedeça a uma regra. A ordenação acentua-se nas obras da série Narrativas. Em Narrativa III (Frase) (1957) [Fig.15], por exemplo, é outra a relação entre os planos de cor e o fundo, que se torna homogêneo, neutro.

A insinuação do espaço urbano e de elementos arquitetônicos retorna na série Os Episódios, iniciada na passagem dos anos 1950 para os 1960. Nesse momento, as pinturas de Leontina estruturaram-se a partir de uma apurada meditação geométrica, ordenadora dos elementos. Mesmo em telas desse tipo, é possível notar "a pulsação de um lirismo inato", ao mesmo tempo em que é mantido um sugestivo "arcabouço arquitetônico, a cor e a composição oscilando entre o delimitado e o livre" (Pontual, 1978b: 64).

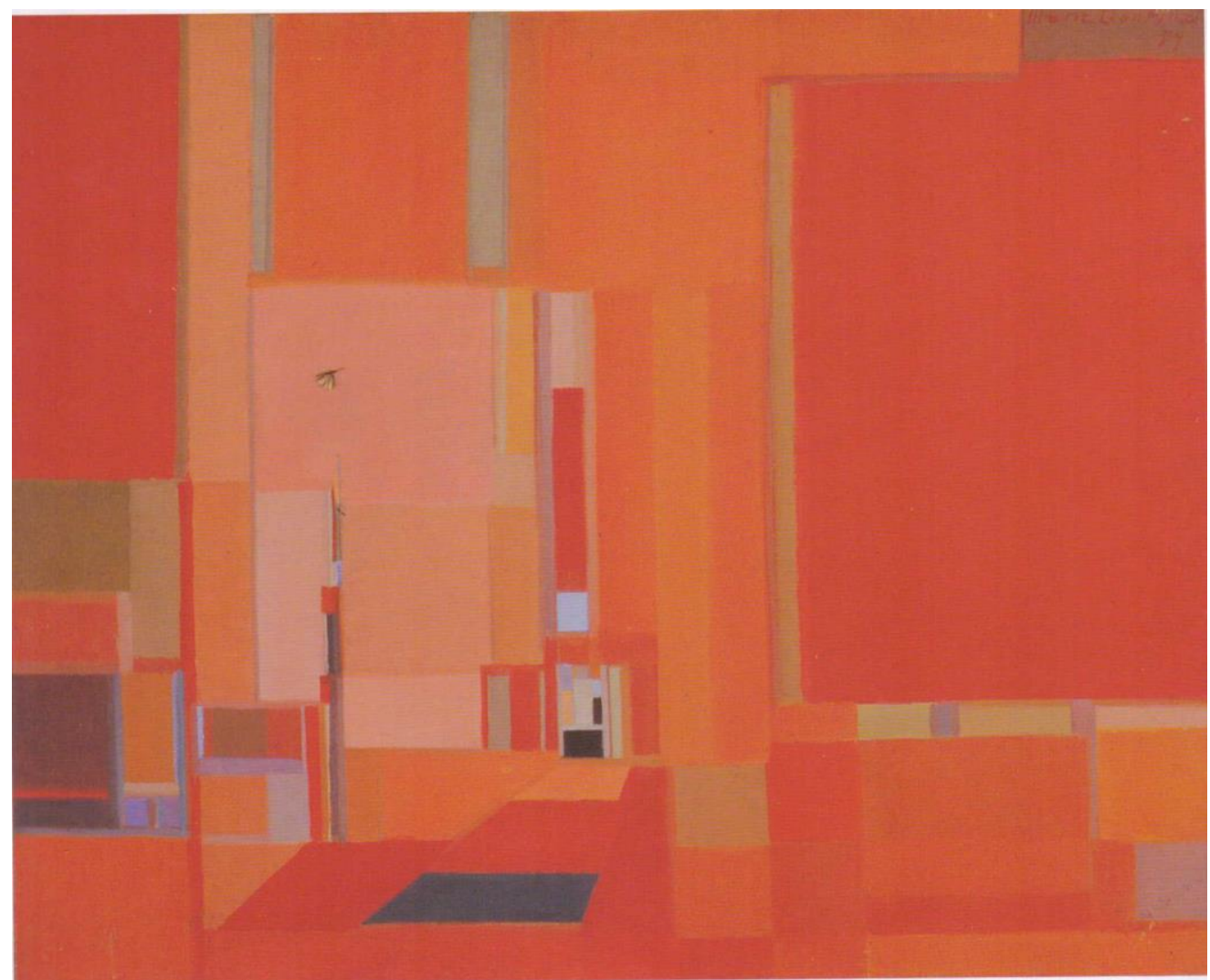

Fig. 10. Maria Leontina. Os Episódios V, 1959, óleo s/ tela, 74 x 92,5 cm. Pinacoteca do Estado de São Paulo. Fonte: Venancio Filho, 2008: 138.

Um exemplo é a tela que pertence à Pinacoteca de São Paulo, Os Episódios V (1959) [Fig.10], em que a percepção do espaço oscila entre literalidade e representação. Por um lado, podemos ver a superfície como arranjo de planos mais ou menos amplos, com predominância de cores quentes e alguns poucos ocres e azuis. Ao mesmo tempo, a sequência de quadriláteros na base da pintura (preto, vermelho e laranja, com as únicas diagonais da composição) constrói a sugestão de perspectiva, formam um caminho que conduz a uma espécie de porta, ativando a percepção de que se trata de um ambiente arquitetônico ou de um espaço urbano. A questão toda do quadro está posta nessa sequência de trapézios, são eles que indagam se os vemos como três figuras geométricas planas justapostas ou 
como três retângulos sequenciados em perspectiva, avançando para dentro do plano. Dependendo da resposta, todo o restante da tela se reconfigura. Outra tela da mesma série pertence à coleção do Museum of Fine Arts de Houston, Os Episódios II (1959) [Fig. 11]. Aqui, a paleta é totalmente diferente da tela da Pinacoteca: a predominância de cores frias acinzentadas, equilibradas intuitivamente, cria uma atmosfera de nostalgia quase melancólica. Em comum, as alusões arquitetônicas na estrutura geometrizada -- a figura preta na base formando degraus, os círculos à direita que sugerem uma luminária. À direita, uma ampla área permanece em branco, um espaço ocupado apenas pela cor neutra. Porém, não há a sensação de inacabado, pois o branco se integra ao restante da composição e "ativa" o que poderia ser um espaço negativo, vazio.

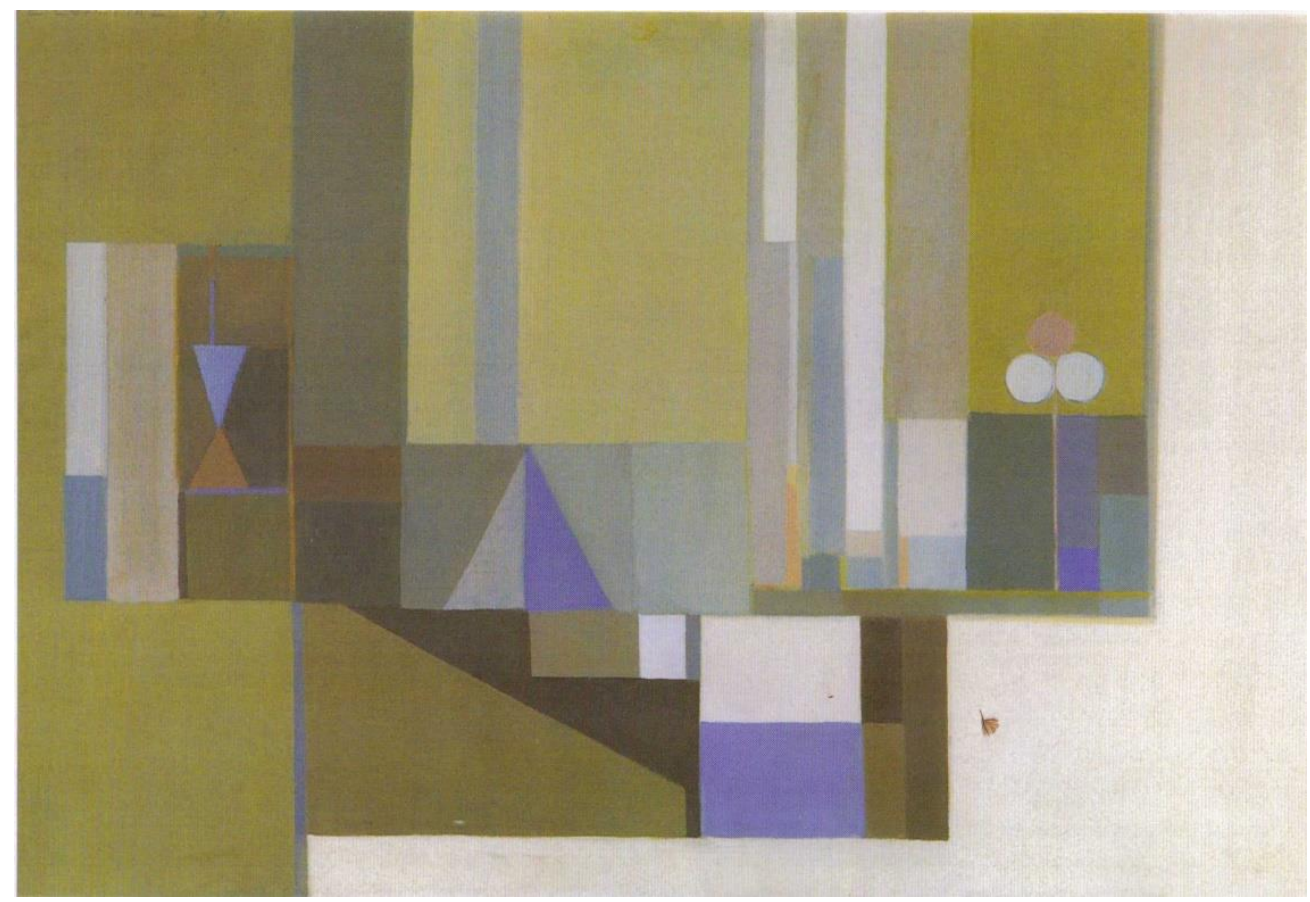

Fig. 11. Maria Leontina. Os Episódios II, 1959, óleo s/ tela, 50 × $90 \mathrm{~cm}$. Museum of Fine Arts, Houston. Fonte: Venancio Filho, 2008: 146.

No início da década de 1960, inicia-se uma nova série, mais um desdobramento da convivência entre abstração e figuração. Estandarte V (1963) [Fig.12], da coleção do MAC USP, tem elementos planos e espaço raso, porém desaparecem os fragmentos coloridos. As áreas de cor perdem definição nos contornos, flutuam num espaço aquoso. A paleta se transforma, é das mais austeras: dois brancos, preto, cinza grafite. $O$ vínculo com o mundo visível também se transforma, acontece agora através do título, que alude a um objeto real. $O$ jogo de ambiguidades e instabilidades semânticas prossegue: um estandarte é em si mesmo uma representação - ele simboliza algo nas manifestações de rua, novenas e desfiles, seja uma instituição, uma fé ou uma família. Aqui, no entanto, a representatividade inerente ao objeto aludido é silenciada, esvaziada. É um estandarte mudo, que não representa nada para além de si mesmo e, portanto, nesse sentido, concretíssimo.

A dinâmica de ambuiguidades entre representação e abstração está também em Pintura IV (1967) [Fig. 13], pertencente à Pinacoteca de São Paulo, exemplo de outra série que Leontina desenvolve nos anos 1960. Se antes havia o estandarte não-estandarte, agora a pintura é Pintura, nome e coisa coincidem 
literalmente. As cores fortes, trabalhadas no contraste, distanciam-se do cromatismo delicado de outrora. Vermelho e laranja escorrem como lava sobre a superfície da tela, o preto se esparrama como piche, o verde pende pesadamente.
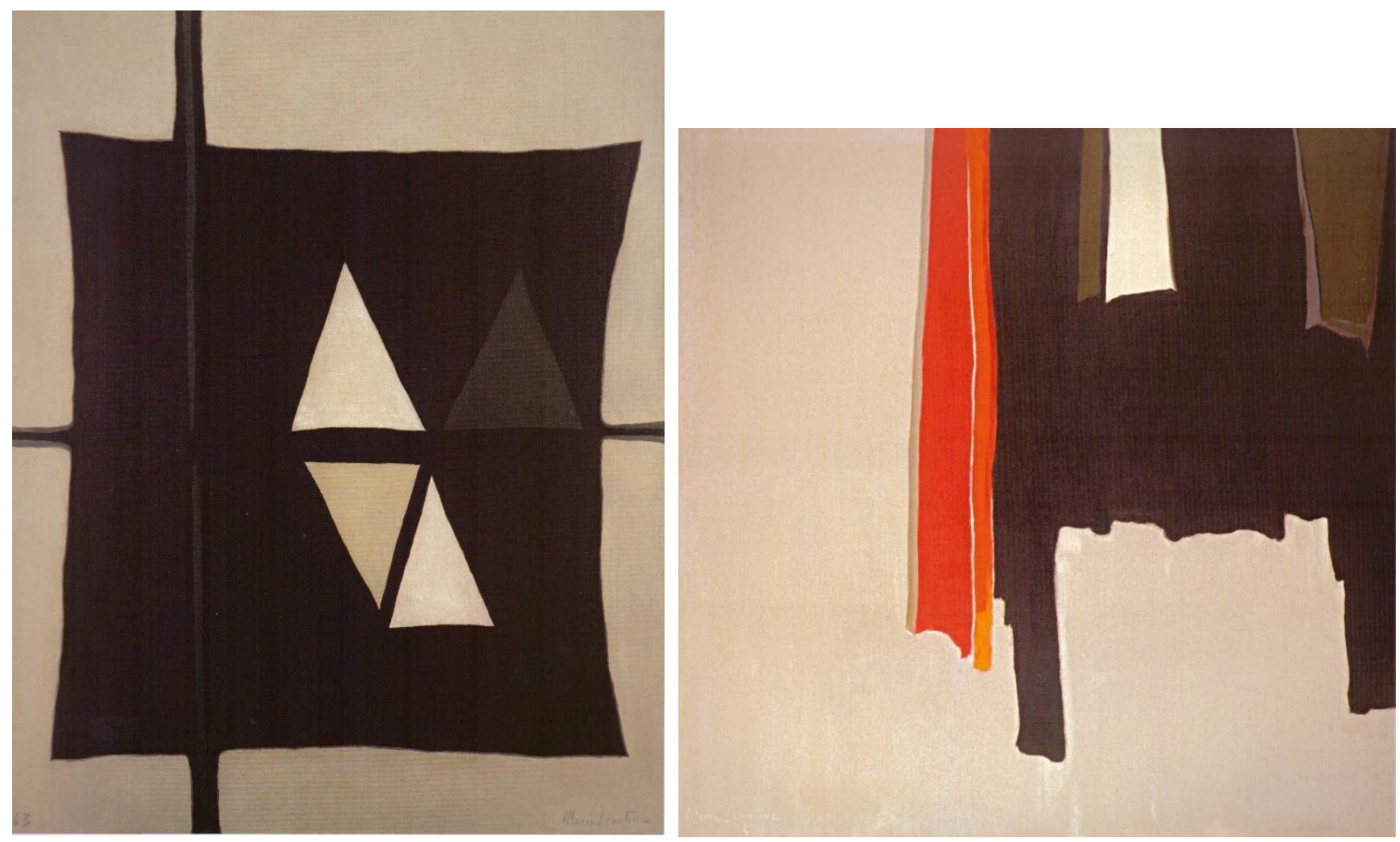

Fig. 12. Maria Leontina. Estandarte V, 1963, óleo s/ tela, 100,6 x 81,3 cm. Coleção MAC-USP. Fonte: Herkenhoff, 2010: 197. Fig. 13. Maria Leontina. Pintura IV, 1967, óleo s/ tela, $150 \times 150 \mathrm{~cm}$. Pinacoteca do Estado de São Paulo. Fonte: Herkenhoff, 2010: 29.

2.

O catálogo da exposição América Latina: geometria sensível traz a seguinte reflexão do pintor Joaquín Torres García:

Falamos muito de geometria, mas convém colocarmo-nos de acordo sobre o que entendemos por isso. Porque há duas espécies de geometria: uma, intuitiva, podemos dizer espiritual; e a outra, feita com a régua e o compasso. A primeira é a que nos serve, não a segunda. Ao traçar a estrutura de um objeto, é a intuição que nos deve guiar a mão (Torres García, 1978: 129).

O pintor uruguaio delimita duas geometrias: aquela que ele recusa e que é projetiva, racional e impessoal. Pensemos em Theo van Doesburg ou Waldemar Cordeiro, por exemplo. Acolhida pelo pintor é a geometria que pode ser associada ao espiritual; a referência é, sem dúvida, Kandinsky, e também Klee. $\mathrm{O}$ que mais me interessa aqui, no entanto, é o modo como Torres García articula estrutura e intuição. Recusando a racionalidade concretista, o que conduz o estruturar, em sua visão, é o intuir, e não o cálculo projetivo. Uma das consequências mais interessantes desse postulado é que ele produz, de saída, uma fissura nas certezas, inocula na obra uma inevitável instabilidade pois, afinal de contas, 
é um risco retirar a estrutura, nada menos que ela, das mãos da matemática, que funciona segundo uma lógica que podemos conhecer, e confiá-la à misteriosa intuição, cujo funcionamento, sem lei alguma, nos escapa totalmente. Abre-se espaço, no espaço da geometria, para a dúvida, a ambiguidade, a incerteza, o imprevisível, o inefável e até mesmo o invisível (lembrando da célebre frase de Klee, que dizia que a arte tornava visível o invisível).

O pintar como ato intuitivo aparece em depoimentos de Maria Leontina. Neste que reproduzo a seguir, tanto o tema quanto os termos usados por ela assemelham-se àqueles da declaração de Torres García:

Ao enfrentar o que lhe é imposto por si mesmo, no processo interior do ato plástico, compulsivo ou sereno, o artista deve fazer o que naquele instante o domina. Deixar-se levar pelo momento que o dirige para encaminhar e completar o que durante todo tempo flui dentro dele, na vivência cotidiana com o seu núcleo, seu refúgio estético, o conteúdo em constante elaboração inconsciente. $O$ trabalho subliminar, depois tornado concreto, pensado todas as horas, nos diversos estados de tranquilidade ou tensão, é a sua verdade, transmitida pelos temas que vão brotando de sua natureza intuitiva ou racional. (...) No apaixonado jogo da imaginação com a razão, ambas têm que ser dosadas (Maria Leontina, 2008: $212-214)^{5}$.

O que está em discussão, tanto na declaração de Torres García quanto no depoimento de Maria Leontina, é a relação entre razão e intuição no ato pictórico. No entanto, se para o pintor uruguaio a relação é de exclusão entre uma e outra, para Leontina a conciliação é admissível e mesmo desejável. Penso que um dos sentidos possíveis de "geometria sensível", aplicada à obra da artista brasileira, estaria nessa procura pela justa medida, no jogo bem jogado, no domínio da "dialética da régua-ecompasso e do exercício espontâneo" (Pontual, 1978b: 64).

Encontramos nesta fala de Leontina a ideia de que a pintura segue um certo fluir interno da/o artista, o ato plástico seria um "processo interior", em comunicação com as emoções de quem o formaliza, via elaboração lírica. Ao longo da história, Construtivismo e Informalismo estabeleceram-se como as duas principais vertentes do abstracionismo. A diferença fundamental entre elas está na compreensão antagônica de cada uma sobre o impulso gerador da obra de arte: "enquanto o Construtivismo, e em particular o Concretismo, atribui à razão um papel essencial, o Informalismo parte da expressão sensivel, intuitiva, do artista" (Cocchiarale; Geiger, 1987: 22), com destaque para a atuação do inconsciente.

Seria equivocado afiliar Maria Leontina ao Informalismo, dada a estruturação e o emprego do vocabulário geométrico em sua obra (ainda que esse vocabulário esteja ausente de várias telas suas, como aquelas feitas a partir da década de 1960, por exemplo). No entanto, a artista tangencia a posição informal, na medida em que considera a sensibilidade, a intuição e o inconsciente como fontes da expressão, o que contribui para compreendermos o interesse dela pela arte dos doentes mentais e sua atuação, a convite do psiquiatra Osório César, como orientadora da Seção de Artes Plásticas do Hospital Psiquiátrico do Juquery, em Franco da Rocha (SP), em $1950^{6}$.

É interessante observar que o envolvimento com a arte dos doentes mentais permite aproximar a expressão "geometria sensível" das considerações feitas por Mário Pedrosa a respeito da "natureza afetiva da forma". Em "Learning from madness", Kaira Cabañas analisa o projeto crítico de Mário Pedrosa e mostra como a colaboração com a Dra. Nise da Silveira e a recepção do trabalho dos pacientes do Hospital Psiquiátrico do Engenho de Dentro informaram uma mudança no cerne desse projeto. Pedrosa, contemporâneo de Leontina e autor de alguns textos sobre sua obra, passa então a 
"articular os contornos de um campo discursivo no qual a geometria seria entendida como expressiva e não racional ou puramente visual" (Cabañas, 2015: 46). O corpo-a-corpo com as obras dos artistas "alienados", a intuição como fundamento do trabalho criativo e o postulado da arte enquanto "necessidade vital" (portanto inerente também a pacientes psiquiátricos, crianças e "primitivos") conduzem os interesses de Pedrosa ao estudo da Gestalt fisionômica, ou seja, a uma compreensão da percepção consoante à expressão, em oposição à Gestalt formal ou estrutural, centrada nos padrões organizacionais da percepção (Cabañas, 2015: 61). Como exemplo, poderíamos pensar no modo como uma paisagem é percebida através do que o crítico chama de "atitude estética": encontramos certa "expressão na paisagem", que é apreendida, em nossa experiência, de modo fisionômico, ou seja, dizemos que determinada paisagem é alegre ou triste, agradável ou assustadora, mesquinha ou generosa, etc. (Pedrosa, 2015b: 147). A interpretação afetiva das formas aconteceria igualmente no caso da obra de arte:

O fenômeno artístico consiste, no fundo, em ver tudo fisiognomicamente, como se se tratasse de um conjunto de planos e linhas animados de expressão, isto é, uma cara, um todo. As formas exteriores se apresentam aos nossos sentidos, ao nosso pensamento, dotadas de vida, como o corpo, o rosto dos seres humanos (Pedrosa, 2015b: 148).

Ele [o objeto de arte] é dotado precisamente desse poder fisionômico que tão bem compreendemos, que 0 animal compreende, que a criança compreende, num rosto (Pedrosa, 1979: 64).

Se Pedrosa não utiliza a expressão "geometria sensivel" em seus textos sobre percepção e psicologia da arte $^{7}$, tampouco naqueles publicados sobre Maria Leontina, creio ser possível, no entanto, aproximar o termo à ideia de "natureza afetiva da forma", pedra de toque de suas análises, e que ele estende à abstração geométrica quando afirma que "as qualidades fisionômicas do todo (...) são características também na figura geométrica, num quadro" (Pedrosa, 1979: 74).

É desse modo que Pedrosa nota, em trabalhos de Leontina do final da década de 1950, um investimento subjetivo na expressividade das formas geométricas. No artigo "Maria Leontina no Tenreiro", publicado no Jornal do Brasil, ele escreve:

Há uma fantasia certa nessas construções e nessas engrenagens, que lembram por vezes corta-ventos, torres, brinquedos de criança; as cores aí são francas, um azul, um vermelho ou um branco ou um preto, e contrapostas por zonas coloridas intermédias, onde predominam cinzas, verdes, laranja, marrom. Essas passagens tocam de doçura aqueles mecanismos, como a indicar que não são eles oriundos da mecânica mesmo, mas antes de um talvez caprichoso lirismo (Pedrosa, 1958: 6).

Não passaram despercebidas ao crítico as alusões a objetos (engrenagens, torres, brinquedos) que, como tenho argumentado, transitam entre forma geométrica pura e figuração.

3.

Afirmei anteriormente ser possível aproximar o posicionamento estético de Leontina de postulados do Informalismo: sensibilidade, intuição e inconsciente como fontes da expressão. Essa concepção, no entanto, não implica a renúncia à ordenação dos elementos, pois o que se recusa aqui, tanto no caso dos informais quanto no de Leontina, é a noção de ordem entendida como norma plástica que antecede 0 ato. Ao invés de partir de um a priori estético, defende-se que 0 ordenamento da obra aconteça internamente, a partir dela mesma e das dificuldades específicas que aparecem ao longo de um processo de formalização que é singular, alcançando-se assim soluções expressivas precisas. Trata- 
se, portanto, "de um tipo de ordem essencialmente atenta a tudo o que ocorre no ato pictórico, inclusive ao acaso, que passa a pertencer à estrutura da obra" (Cocchiarale; Geiger, 1987: 23).

Como consequência, não há hierarquia pré-estabelecida entre os elementos pictóricos -- espaço, cor, forma -- e não faz sentido a imposição de um vínculo definitivo entre eles. Se um elemento preside os demais, isso decorre da organização plástica da obra dada em função das necessidades expressivas do/a artista. Tais necessidades, creio, são o que Maria Leontina chama de "núcleo complexo interior", em depoimento no qual comenta o processo criativo:

Numa construção proposta, em que o quadro é dividido irregularmente, os elementos dispostos acima ou abaixo, à esquerda e à direita de uma linha divisória - insinuação de um mundo subterrâneo ou aéreo, subjetivo ou objetivo - ou as formas agrupadas umas sobre as outras, como se também o fundir das cores representasse o núcleo complexo interior, o artista concentra a sua proposta organizada no que the parece mais coerente para simbolizar uma "frase" plástica, dentro do enigma da comunicação com aquele que vai assistir e interpretar o seu processo (Maria Leontina, 2008: 213).

O depoimento faz referência direta à série Narrativas [Fig.15], do final da década de 1950. Nas pinturas desse conjunto, subsiste algo de natureza-morta: a artista evoca as composições praticadas anteriormente, entre os anos 1940 e 1950, ao distribuir, aproximar e relacionar retângulos, triângulos e meio-círculos com o mesmo cuidado que dispensava às jarras, taças e bules, atenta à aproximação equilibrada dos planos. Como já notou Aracy Amaral, a obra de Giorgio Morandi teve forte impacto nos artistas modernos brasileiros ${ }^{8}$, inclusive Maria Leontina e seu marido, Milton Dacosta ${ }^{9}$. Seria natural procurar as influências de tão célebre pintor de naturezas-mortas entre os quadros do mesmo gênero de Leontina - como mostrei aqui, ela produziu várias telas desse tipo no período inicial da carreira. Mas as naturezas-mortas dela são compostas na obliquidade do espaço cézanniano, muito diferente do procedimento morandiano de alinhar os objetos num plano paralelo ao da superfície do quadro. Além disso, nessas telas Leontina não hesita em explorar cores fortes e o nervosismo da pincelada expressionista, incompatíveis com o equilíbrio sereno das composições do pintor italiano.
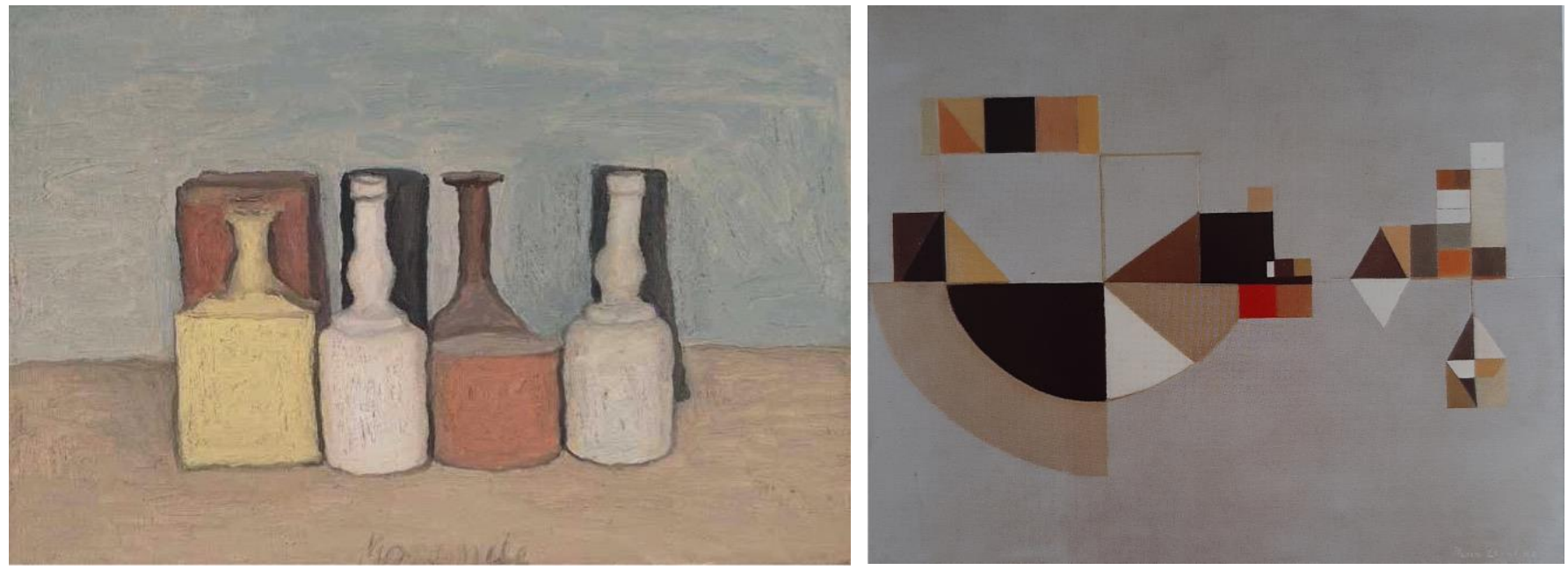

Fig. 14. Giorgio Morandi. Natura morta, 1956 (V.985) , óleo s/ tela, 30 x 45 cm. Col. Museo Morandi, Bologna. Fonte: Massi, 2012: 61). Fig.15. Maria Leontina. Narrativa III (Frase), 1957, óleo s/ tela, 65 x 80 cm. Col. Particular, São Paulo. Fonte: Morais, 1999: 70. 
Acredito que as relações com a pintura de Morandi tornam-se visiveis nos trabalhos do final da década de 1950, na série Narrativas, por exemplo. Ao compararmos Narrativa III (Frase) [Fig. 15] e a Natura morta [Fig. 14] de Morandi, notamos como Leontina absorve o esquema compositivo do mestre bolonhês, ao mesmo tempo em que o reelabora segundo seus próprios interesses plásticos. Se olharmos os objetos de Morandi como figuras mais ou menos geométricas, encontramos um procedimento semelhante ao da tela de Leontina: uma linha horizontal que atravessa o plano de fora a fora dá início ao jogo de distribuição de formas geométricas ou campos de cor ao longo desse eixo inicial, acima e abaixo dele, numa sucessão de rebatimentos não equivalentes e não simétricos ${ }^{10}$.

A pintora traduz representações figurativas em formas geométricas, radicaliza o procedimento de abstração que o poeta Murilo Mendes observou em Morandi, o qual, "tendo por base a realidade, separa determinados elementos com o escopo de operar uma redução essencial" (Mendes, 2012: 99). Observando o pintor italiano, Leontina planifica a geometria, o que the permite desenvolver como solução construtiva uma estrutura de planos empilhados (presente também em Dacosta), que ela explora em outras séries, como Os jogos e os enigmas, Da paisagem e do tempo e Episódios ${ }^{11}$. Se Murilo Mendes, valendo-se do poder de síntese que é privilégio dos poetas, considerava Giorgio Morandi "um abstrato em campo figurativo" (Ibidem), pergunto-me se não seria Leontina uma figurativa em campo abstrato.

\section{4.}

Vimos, a partir da abstração informal, que o condicionante da ordem interna de cada tela é uma dada intenção expressiva particular, e não uma norma estabelecida de antemão. No entanto, é necessário sublinhar uma exceção, pois o Informalismo prescreve o princípio a priori da não-representação, que exclui a figura e, com ela, a referência à realidade exterior, para dar lugar à expressão da subjetividade do/a artista (Cocchiarale; Geiger, 1987: 23). Nisso está a fronteira que separa a pintura de Maria Leontina daquela dos informais, pois para a artista, como temos visto, a figuração não é entrave ao livre fluir da expressão subjetiva, mas sim uma de suas modalidades. "Desde menina eu me apaixonava pelos objetos como os outros se apaixonam pelas pessoas" (apud Ayala, 2008: 68), conta a pintora. A paixão faz fantasiar, cria anseios de possibilidades ainda desconhecidas, torna-nos disponíveis ao inédito, constrói novas memórias. Sobretudo, creio, "apaixonar-se por um objeto" resume a opção pela convivência cuidadosa, que não domina nem oprime, antes preserva e aprimora. Dentre milhares de outros, o objeto da paixão torna-se único, como únicas serão suas relações dentro de uma tela, como única será essa mesma tela. Não à toa, os mecanismos da paixão são tão misteriosos quanto aqueles da intuição, ambos equidistantes da racionalidade.

A presença da figura é a marca da memória, do contato do corpo com o mundo, da experiência sensível. Sugerir a figuração é um recurso desenvolvido por Leontina para instilar na tela algo da subjetividade. Leontina não quer extirpar da pintura o mundo da empiria, quer antes borrar as fronteiras entre ele e 0 mundo abstrato da planaridade pictórica, problematizando e ao mesmo tempo afirmando um pelo contato com o outro. Por um lado, essa prática serve como antídoto à impessoalidade do projeto concretista, é um modo de resistir à completa objetivação do quadro, entendido como produto. Por outro lado, ao operar com a linguagem geométrica, Leontina resiste igualmente à dissolução tachista da forma.

O sobrevoo pelas telas de Leontina demonstrou o cultivo, ao longo de décadas, de vínculos variados entre figura e forma abstrata; cultivo esse que envolvia questionar, investigar, testar os limites da relação entre ambas. Penso que a convivência entre dois regimes de visualidade aparentemente opostos 
permite-nos apreender a noção de forma que orientava as obras de Leontina, a saber, a busca nunca concluída pela conciliação entre estrutura geométrica e subjetividade. Essa conciliação nunca plenamente resolvida é, a meu ver, o que anima o termo "geometria sensível" e esclarece sua aplicação à obra de Maria Leontina. $O$ que interessava à pintora não era resolver a partida. 0 desafio e a busca de sua arte estão em criar possibilidades de manter o jogo irresolvido, recusando o unívoco, o previsível, os significados impostos a priori.

Este aspecto permite vislumbrar relações com a pintura de Alfredo Volpi, que Leontina conhecia bem. $\mathrm{Na}$ obra do pintor do Cambuci é igualmente tênue a distinção entre forma geométrica pura e figuração ${ }^{12}$. Elementos recorrentes em várias telas são usados de modo ambíguo, são eles mesmos e representam outras coisas, a depender do contexto plástico e da maneira como olhamos. Numa tela concreta, a célebre bandeirinha pode ser forma geométrica - um quadrado do qual subtraiu-se um triângulo -, porém se incluída numa tela de sugestão figurativa, volta a ser a representação de uma bandeirinha. 0 mesmo vale para a meia-lua, frequente nas telas do pintor: pode ser forma abstrata, ou ainda lua, onda, peixe, barco. No ensaio que escreveu sobre 0 artista, Lorenzo Mammì afirma que o cerne formal do trabalho de Volpi está em manter "o jogo de ilusão e literalidade" (Mammì, 2001: 37), e que o percurso do artista desde o início da década de 1930 até meados da década seguinte poderia ser descrito como "uma busca progressiva de soluções formais sempre mais tensas, equilíbrios sempre mais precários" (Ibidem: 17). Acredito que um raciocínio semelhante valeria para Maria Leontina, pois tampouco a ela interessava apaziguamentos - que não devem ser confundidos com a delicadeza que de fato há em sua arte. Sustentar a tensão entre a literalidade do signo e a ilusão da representação era questão que a movia, e que definia a qualidade dos vínculos que buscava entre os diferentes elementos empregados na formalização das obras.

Se partíssemos de uma atitude teleológica da história da arte, automaticamente veríamos nas obras do final dos anos 1940 e da década de 1950 a transição da figuração à abstração. Seriam etapas necessárias para que a artista fosse aos poucos aprendendo a "purificar" as formas de sua função imitativa ou representativa, de modo a alcançar a terra prometida da abstração plena, rompendo em definitivo com a figura. Ora, parece-me evidente que nos anos 1950 a artista já sabia muito bem como executar uma abstração tout court. É uma questão de escolha que não o tenha feito em várias ocasiões - e que de fato o tenha feito, em outras. Não é que ela não fosse capaz de abandonar a figura, ou que traísse algum conservadorismo ao não fazê-lo. Creio que sua preocupação estava em explorar a convivência, ou a justaposição das duas possibilidades, em conferir imprecisão à figura de modo a evidenciar os laços íntimos com a abstração.

Afirmar a geometria com a ênfase dos concretos demandaria uma atitude de certeza em relação ao mundo e ao visível que Leontina não estava disposta a assumir. O lirismo ou o "sensível" que críticos enxergaram em sua arte tem como base, acredito, uma atitude de dúvida, de suspensão, de busca do ambivalente. É expressão de um sujeito que desconfia dos limites bem postos, das fronteiras bem definidas, da pretensão de universalidade das definições. Se o mundo ainda abriga mistérios e se deixa captar apenas parcialmente, como submetê-lo a um projeto?

Certa vez, em depoimento ao crítico Frederico Morais, Leontina disse: "Quando vejo a montanha, o contorno me parece inicialmente definido. Depois surgem duas, três linhas. $O$ mesmo ocorre em nosso relacionamento com os seres humanos. O que era nítido de início, cede lugar à imprecisão" (apud Morais, 1999: 10). Considero essa fala muito bonita, por algumas razões. Primeiro, pela referência discreta a Cézanne e sua Sainte-Victoire, a mistura de fascinação e obsessão por uma coisa ("Quando 
menina me apaixonava por objetos"). Gosto de imaginar, num anacronismo fantástico, os dois pintores sentados lado a lado diante da mesma janela, observando ao longe a montanha que é a Sainte-Victoire para ele e o Corcovado para ela, ambos inventando maneiras de captar a forma. $O$ que me traz à mente um belo retrato em que Leontina observa alguma coisa ao longe, e seu olhar é tão distante quanto introspectivo (Venancio Filho, 2008: 228) [Fig. 16]. Aprecio a declaração também porque ela permite compreender que para a pintora a realidade exterior é pergunta, e não resposta. $O$ visível não guia nem condiciona a figuração, mas coloca o problema cuja solução, mesmo provisória, caberá à formalização sensível. A figura, portanto, é uma questão em aberto, não se deixa apreender por completo, é um desafio ou, para usar uma palavra de que Leontina gostava, um enigma.

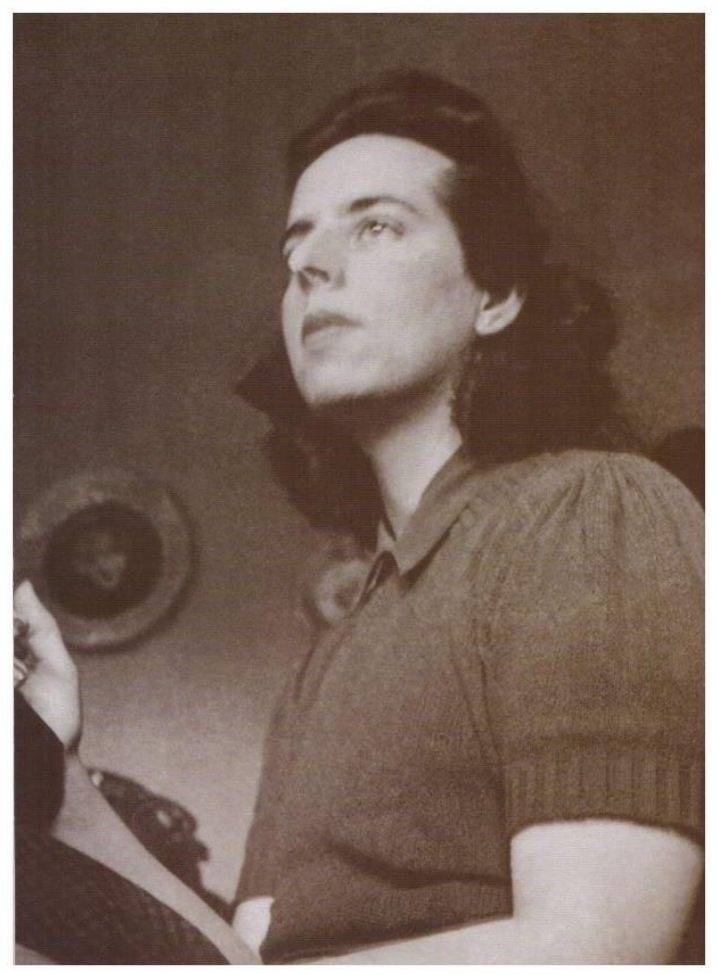

Fig. 16. Retrato de Maria Leontina por fotógrafo desconhecido, s.d. Fonte: Venancio Filho, 2008: 228.

\section{Referências}

AMARAL, A. Morandi: os artistas e a crítica do Brasil. In: MASSI, A. Morandi no Brasil. Porto Alegre: Fundação lberê Camargo, 2012.

ANÔNIMO. Encontro com Maria Leontina. Tribuna da Imprensa, Rio de Janeiro, p.16-17 ago.1952, p. 9.

ANÔNIMO. Fala Maria Leontina, consagrada pintora paulista. Diário de Notícias, Rio de Janeiro, p.7. 13 mar. 1955.

AYALA, W. Em torno de Maria Leontina. Jornal do Commercio, Rio de Janeiro, 11 fev. 1979. Reproduzido em VENANCIO FILHO, P. et al.
Maria Leontina: pintura sussurro. São Paulo: Arauco Editora, 2008.

CABAÑAS, K. M. Learning from madness: Mário Pedrosa and the physiognomic Gestalt. October 153, p. 42-64, verão 2015.

CARVALHO, R. de. A formação do pensamento estético de Osório César: estudo dos textos sobre arte e cultura escritos no período de 1920 a 1960. 2016. Tese (Doutorado em História) IFCH/UNICAMP, Campinas, 2016.

COCCHIARALE, F.; GEIGER, A. B. (orgs.). Abstracionismo, geométrico e informal: a 
vanguarda brasileira nos anos cinquenta. Rio de Janeiro: FUNARTE, Instituto Nacional de Artes Plásticas, 1987.

FERRAZ, G. Retrospectiva Waldemar da Costa: exposição homenagem ao mestre. São Paulo: MAM, 1972.

HERKENHOFF, P. Maria Leontina. Rio de Janeiro: Papel e Tinta, 2010.

MACIEL, A. Waldemar da Costa: alguns aspectos da sua pintura. Curitiba: MAC, 1981.

MAMMì, L. Volpi. São Paulo: Cosac \& Naify, 2001.

MARIA LEONTINA. Depoimento no X Salão de Arte Contemporânea de Campinas. 1975. In: VENANCIO FILHO, P. et al. Maria Leontina: pintura sussurro. São Paulo: Arauco Editora, 2008.

MASSI, A. O tempo interior de Giorgio Morandi. In: _. Morandi no Brasil. Porto Alegre: Fundação Iberê Camargo, 2012. Disponivel em: $<$ http://iberecamargo.org.br/wpcontent/uploads/2018/10/catalogo_giorgiomorandi-no-brasil.pdf>. Acesso em 18. dez. 2020.

MENDES, M. Morandi: um abstrato em campo figurativo. In: MASSI, A. Morandi no Brasil. Porto Alegre: Fundação Iberê Camargo, 2012.

MORAIS, Frederico. A pintura como silêncio. In: (cur.). Milton Dacosta e Maria Leontina: um diálogo. Rio de Janeiro: CCBB, 1999.

PEDROSA, M. Maria Leontina no Tenreiro. Jornal do Brasil, Rio de Janeiro, p. 6, 01 fev. 1958

Da natureza afetiva da forma na obra de arte. In: Arte, forma e personalidade: 3 estudos. São Paulo: Kairós, 1979, p. 12-82. (Publicado originalmente em 1949).

Arte, necessidade vital. In: MAMMì, L. $\overline{\text { (org.). }}$ Mário Pedrosa: arte: ensaios. São Paulo:
Cosac Naify, 2015a, p. 48-67. (texto publicado originalmente em 1947).

Forma e personalidade. In: MAMMì, L. (org.). Mário Pedrosa: arte: ensaios. São Paulo: Cosac Naify, 2015b, p. 129-177. (texto publicado originalmente em 1951).

PÉREZ-BARREIRO, G.; SOMMER, M. (orgs.). Mário Pedrosa: de la naturaleza afectiva de la forma. Madri: Museo Nacional Centro de Arte Reina Sofía, 2017. Disponível em: $<$ https://issuu.com/museoreinasofia/docs/mario _pedros_baja>. Acesso em: 18 dez. 2020.

PONTUAL, R. Do mundo, a América Latina. Entre as geometrias, a sensivel. In: América Latina: Geometria Sensivel. Rio de Janeiro: Edições Jornal do Brasil, 1978a.

Brasil: as possíveis geometrias. In: América Latina: Geometria Sensível. Rio de Janeiro: Edições Jornal do Brasil, 1978b.

TORRES GARCÍA, J. Recuperación del Objeto, 1949. In: PONTUAL, R. América Latina: Geometria Sensivel. Rio de Janeiro: Edições Jornal do Brasil, 1978.

VENANCIO FILHO, P. Maria Leontina: pintura sussurro. In: Maria Leontina: pintura sussurro. São Paulo: Arauco Editora, 2008.

ZAGO, R. Os Salões de Arte Contemporânea de Campinas: 1965-77. In: COLÓQUIO DO COMITÊ BRASILEIRO EM HISTÓRIA DA ARTE, 23., 2008, Rio de Janeiro (RJ). Anais... Rio de Janeiro: CBHA, 2009, p.212-219. Disponível em: $<$ https://hosting.iar.unicamp.br/vanguardasemc ampinas/downloads/comuc_renatazago.pdf>. Acesso em: 27 set. 2020.

ZANINI, W. (org.). História geral da arte no Brasil. São Paulo: Instituto Walther Moreira Salles, 1983. $2 \mathrm{v}$.

\section{Notas}

\footnotetext{
* Doutora em História da Arte pela Universidade Estadual de Campinas (Unicamp). Este artigo é fruto de minha pesquisa de pósdoutorado, em andamento no Instituto de Estudos Brasileiros da Universidade de São Paulo (IEB-USP), com financiamento do CNPq. E-mail: <prisacchettin@gmail.com>. ORCID: <https://orcid.org/0000-0002-5756-2077>.

${ }^{1}$ Como evidência desse interesse crescente, o curador cita a seguinte sequência de eventos: Simpósio de Arte e Literatura realizado na Universidade do Texas, em Austin (1975), o expressivo conjunto de obras de latino-americanos na Bienal de Paris (1977), Reunião Interamericana de Diretores de Museus de Arte em Oaxaca, I Bienal Ibero-Americana de Pintura do México, I Encontro Ibero-Americano de Críticos de Arte e Artistas Plásticos em Caracas e a I Bienal Latino-Americana de São Paulo, com o tema Mitos e Magia (estes quatro eventos em 1978).
} 
${ }^{2}$ A mostra tem um destino trágico: as obras são destruídas no grande incêndio do dia 8 de julho, que compromete a estrutura do edifício e consome a coleção do MAM-RJ.

${ }^{3}$ As relações da pintura de Maria Leontina com a arte latino-americana fogem ao escopo deste texto e mereceriam um artigo à parte. Por ora, vale notar apenas a participação da pintora em diversas exposições ocorridas no continente: Pintura brasileña contemporánea, Universidade do Chile, Santiago e Exposición del Brasil en Chile, Valparaíso, Chile (ambas em 1946); Pintura brasileña contemporánea, Instituto de Cultura Uruguaio-Brasileño, Montevidéu (1956); Arte Moderno en Brasil, Museu Nacional de Belas Artes de Buenos Aires, itinerante por Rosario, Santiago e Lima (1957); I Bienal Americana de Arte, Córdoba, Argentina (1962); II Bienal Americana de Arte de Córdoba (1964); I Encontro Ibero-Americano de Críticos de Arte e Artistas Plásticos, Museu Nacional de Belas Artes, Caracas, Venezuela (1978).

${ }^{4}$ A fatura expressionista na pintura de Leontina vem dos anos 1930, está em retratos, paisagens e algumas naturezas-mortas. Resulta das aulas com o pintor Waldemar da Costa (ver Ferraz, 1972 e Maciel, 1981). Não descarto relações também com a pintura de Ernesto de Fiori.

${ }^{5}$ Para a datação do depoimento de Leontina e um comentário sobre o evento em que ele ocorreu (Zago, 2008: 7).

${ }^{6}$ A partir do trabalho no Juquery, Leontina insere-se num histórico de exposições que visavam divulgar e valorizar a produção de doentes mentais: 1933, São Paulo: exposição Mês das Crianças e dos Loucos, organizada por Osório César e Flávio de Carvalho no Clube dos Artistas Modernos (CAM), São Paulo; 1946, Rio de Janeiro: primeira mostra do Setor de Terapêutica Ocupacional e Reabilitação (STOR), fundado no mesmo ano pela psiquiatra Nise da Silveira no Centro Psiquiátrico Pedro II (Hospital Psiquiátrico do Engenho de Dentro); 1947, Rio de Janeiro: exposição de trabalhos dos pacientes do Engenho de Dentro no Ministério da Educação e Saúde. Um recorte dessa mostra foi exposto na Associação Brasileira de Imprensa onde, por ocasião do encerramento, Mário Pedrosa apresentou a palestra "Arte, necessidade vital"; 1949, São Paulo: 9 Artistas do Engenho de Dentro do Rio de Janeiro, curadoria de Léon Degand em colaboração com Mário Pedrosa e Almir Mavignier no MAM SP; 1951, São Paulo: Exposição de Artistas Alienados, organizada por Maria Leontina no MAM SP, com trabalhos de pacientes do Hospital Psiquiátrico do Juquery.

${ }^{7} \mathrm{Em}$ Arte, necessidade vital, Pedrosa menciona uma "perspectiva afetiva", a partir de André Lhote: "Finalmente, o moderno (...) refaz a perspectiva: é uma perspectiva nova, denominada por Lhote de afetiva, para significar que esta não pode mais ser reduzida a nenhuma fórmula exterior, pois a transformação que 0 artista criador impõe à relação natural dos objetos só obedece, e só tem de obedecer, ao ritmo poético, ao ritmo plástico" (Pedrosa, 2015a: 53, grifo do autor).

${ }^{8} \mathrm{Na}$ I Bienal de São Paulo, dez telas de Morandi integravam a mostra da delegação italiana. Na Bienal seguinte, 0 artista participou com 25 águas-fortes que lhe renderam o Prêmio de Gravura. Em 1957, a IV Bienal de São Paulo dedica a ele uma Sala Especial com 30 telas e lhe concede o Grande Prêmio de Pintura. Ver (Amaral, 2012).

${ }^{9}$ Leontina e Dacosta possuíam, em sua coleção particular, um desenho de Morandi (Herkenhoff, 2010: 256).

10 As formas são "lidas" invariavelmente da esquerda para a direita, dado nosso sistema de escrita, o que, no caso de Leontina, justifica o título da série, pois Narrativa III alude ainda ao desenrolar temporal da linguagem verbal, ao encadeamento de signos com ênfases, pausas, interrupções e continuidades.

${ }^{11}$ A propósito da pintura de Leontina no fim da década de 1950, Mário Pedrosa aponta para o "jogo dos planos que, justapondo-se ou superpondo-se, alcança o precário equilíbrio de pedras ou blocos armados no espaço" (Pedrosa, 1958: 6).

${ }^{12}$ A relação entre ambos os pintores não passou despercebida a Gabriel Pérez-Barreiro e Michelle Sommer, curadores da exposição Mário Pedrosa: de la naturaleza afectiva de la forma, que incluía obras de Volpi e de Leontina. A mostra aconteceu no Museo Nacional Centro de Arte Reina Sofía de Madri, em 2017 (ver Pérez-Barreiro; Sommer, 2017). Note-se ainda que, além do contato pessoal com Volpi, Leontina possuía em sua coleção particular uma tela dele (Herkenhoff: 2010, 102).

Artigo recebido em setembro de 2020. Aprovado em novembro de 2020. 